\title{
Clinical assessment of anesthesia with isoflurane and medetomidine in 300 equidae
}

\author{
Karin S. Kalchofner, Simone K. Ringer, Jolanda Boller, Sabine B. R. Kästner, Christoph Lischer and Regula Bettschart-Wolfensberger \\ Clinic for horses, University of Zuerich, Vetsuisse Faculty Zuerich, Switzerland
}

\begin{abstract}
Summary
A new anesthetic protocol for horses was evaluated in 300 clinical patients. Particular attention was paid to cardiopulmonary function and recovery, as poor recoveries and bad cardiovascular function represent the main causes for the high mortality rate associated with equine anesthesia. 300 equidae of mixed breed, mean age of 8 years and mean weight of $486 \mathrm{~kg}$ were anaesthetised. Horses were premedicated with acepromazine IM. Following sedation with medetomidine IV, anaesthesia was induced with ketamine and diazepam IV. Anesthesia was maintained with isoflurane in oxygen and constant rate infusion of medetomidine. Horses were allowed to breathe spontaneously, unless apnea necessitated artificial ventilation. Heart rates, respiratory rates, arterial blood pressure, and composition of inhaled and exhaled gases were monitored continuously. Arterial blood gases were measured regularly. Incremental boli of ketamine or thiopentone were noted. Morphine and medetomidine were administered for recovery. Recovery time was recorded and recovery quality was scored on a $1-5$ scale $(1=$ best, $5=$ worst). Mean duration of anaesthesia was 149 minutes. Hypotension or hypoxemia occurred in a small number of horses. Both resolved when either additional fluids and sympathomimetics or a higher concentration of inspiratory oxygen was administered. 146 horses received supplemental ketamine and 29 thiopentone respectively. Recovery was scored excellent or good in 299 horses, poor in one horse. Mean duration of recovery was 50 minutes. Results suggest that the described anesthetic protocol is suitable to maintain anesthesia in horses for various procedures of considerable duration. Cardiopulmonary function was well maintained and recoveries were of exceptionally good quality.
\end{abstract}

Keywords: Horse, anaesthesia, medetomidine, cardiopulmonary function

\section{Klinische Anwendung von Isofluran/Medetomidin-Anästhesie bei 300 Equiden}

Die Mortaliätsrate in der Pferdeanästhesie ist mit 1 \% sehr hoch. Im Vergleich dazu liegt sie in der Kleintieranästhesie bei lediglich 0.15 \% und in der Humananästhesie bei 0.002 \%. Die drei häufigsten perioperativen Todesursachen beim Pferd sind Herzkreislaufstillstand zu Beginn der Anästhesie, sowie Frakturen und Myopathien während der Aufwachphase. Für längere operative Eingriffe sind heutzutage Inhalationsanästhetika Mittel der Wahl. Diese führen zu einer Beeinträchtigung der Kreislauffunktion und dadurch zu einer verminderten muskulären Durchblutung. Dies fördert die Entstehung oben genannter Myopathien. Eine neue Möglichkeit Pferde sicherer zu anästhesieren bietet der kombinierte Einsatz von Inhalationsanästhetika und Analgetika oder Sedativa. Ein Sedativum mit hervorragenden analgetischen Eigenschaften ist Medetomidin, der zurzeit potenteste und spezifischste $\alpha_{2}$-Agonist. Medetomidin kann aufgrund seiner pharmakokinetischen Eigenschaften beim Pferd während einer Inhalationsanästhesie kontinuierlich infundiert werden. Dies resultiert in einer Verminderung des Bedarfes an Inhalationsanästhetika, stabiler Herzkreislauffunktion sowie ruhigen Aufwachphasen. Ziel der vorliegenden Studie war es, die Anästhesie mit Isofluran und Medetomidin beim Pferd an einer grossen Anzahl klinischer Patienten zu evaluieren. Spezielle Beachtung wurde dabei, aus oben erwähnten Gründen, der Herzkreislauffunktion und der Aufwachphase gewidmet. 296 Pferde und 4 Esel wurden in die Studie einbezogen. Alle Operationsarten, ausser Kolikeroperationen, wurden eingeschlossen. Die Pferde wurden vor der Anästhesie klinisch untersucht und gewogen. Das mittlere Alter der Patienten betrug 8 Jahre, das mittlere Körpergewicht 486 kg. Die Prämedikation erfolgte mit Acepromazin $(0.03 \mathrm{mg} / \mathrm{kg} \mathrm{im}) 30$ Minuten vor der Einleitung. Unmittelbar vor der Einleitung wurden die Pferde sediert mit Medetomidin (7 $\mu \mathrm{g} / \mathrm{kg} \mathrm{IV).} \mathrm{Wenn} \mathrm{die} \mathrm{Sedation} \mathrm{ungenügend} \mathrm{erschien} \mathrm{wurde} \mathrm{eine} \mathrm{zusätzliche} \mathrm{Dosis} \mathrm{Medetomidin} \mathrm{verabreicht} \mathrm{(1-3} \mu \mathrm{g} / \mathrm{kg}$ liv) und die Menge notiert. Anschliessend wurde die Anästhesie eingeleitet mit Ketamin (2.2 mg/kg iv) und Diazepam (0.02 mg/kg iv). Die Pferde wurden danach endotracheal intubiert und die Anästhesie aufrechterhalten mit Isofluran in einem Gemisch aus Sauerstoff und Luft. Zusätzlich wurde während der gesamten Anästhesie Medetomidin (3.5 $\mu \mathrm{g} / \mathrm{kg} / \mathrm{h})$ kontinuierlich infundiert. Die Tiere atmeten spontan, nur bei anhaltender Apnoe (>1 min) wurden sie künstlich beatmet. Atemfrequenz, Herzfrequenz, arterieller Blutdruck und die Zusammensetzung der in- und exspiratorischen Gase wurden kontinuierlich überwacht, arterielle Blutgase wurden regelmässig gemessen. Allen Pferden wurde Ringer Laktat infundiert $(5 \mathrm{ml} / \mathrm{kg} / \mathrm{h}$ ). Dobutamin wurde verabreicht nach Bedarf, mit dem Ziel den mittleren arteriellen Blutdruck zwischen 70 und $90 \mathrm{~mm} \mathrm{Hg}$ zu erhalten. Die maximale Dosis aber betrug $1.25 \mu \mathrm{g} / \mathrm{kg} / \mathrm{min}$. Zeigte ein Pferd Nystagmus, wurde ein Bolus Ketamin verabreicht $(0.1 \mathrm{mg} / \mathrm{kg}$ iv), traten Exzitationen auf wurde Thiopental verabreicht (1 mg/kg iv). Zusätzlich verabreichte Medikamente wurden protokolliert. Die Daver der Aufwachphase wurde notiert und die Qualität auf einer Skala von 1-5 (exzellente Aufwachphaseschlechte Aufwachphase, Pferd verletzt) bewertet. Die mittlere Anästhesiedauer betrug 149 Minuten. Sedation und Einleitung verliefen ruhig bei allen 300 Patienten. Bei 6 Pferden trat eine Hypotension auf (mittlerer arterieller Blutdruck $<60 \mathrm{~mm} \mathrm{Hg}$ ), 7 Pferde zeigten eine vorübergehende Hypoxämie $\left(\mathrm{PaO}_{2}<60 \mathrm{~mm} \mathrm{Hg}\right)$. Aber beide Probleme konnten bei allen Pferden mittels erhöhter Infusionsmenge und Verabreichung von Vasopressoren bzw. erhöhtem inspiratorischem Sauerstoff gelöst werden. 296 Pferde atmeten spontan, 4 mussten künstlich beatmet werden. Bei insgesamt 146 Pferden wurden Ketaminboli verabreicht, bei 29 Pferden Thiopental. Die Erhaltung der Anästhesie wurde von den 6 verschiedenen Anästhesisten als gut steuerbar beurteilt, allfällige Bewegungen der Tiere waren sanft und gut kontrollierbar. Auffällig war, dass die Tiere häufig ausgeprägten Lidreflex zeigten und zum Teil spontan blinzelten. Die mittlere Daver der Aufwachphase betrug 50 Minuten. Die Qualität der Aufwachphase wurde in 299 Fällen mit exzellent oder gut bewertet, als schlecht in einem Fall. Aufgrund der vorliegenden Ergebnisse wird das aufgeführte Anästhesieprotokoll als gut geeignet für längere Anästhesien beim Pferd beurteilt. Die Kreislauffunktion blieb gut erhalten und die Aufwachphase war von ausserordentlich guter Qualität.

Schlüsselwörter: Pferd, Anästhesie, Medetomidin, Isofluran, kardiopulmonale Funktion 


\section{Introduction}

The mortality rate in horse anesthesia is $1 \%$ for animals without systemic illness undergoing routine surgery (Johnston et al. 2004). This is high in comparison with $0.15 \%$ in companion animals (Clarke and Hall 1990) and $0.002 \%$ in man (Gibbs and Rodoreda 2005). The main causes for perioperative death in horses are cardiac arrest or cardiovascular collapse during anesthesia (33\%) and fractures or myopathies impeding the horse's ability to stand up (32\%). Thus the crucial requirements for a safe anesthetic protocol are a well-maintained cardiovascular function and a good recovery phase. A contributory cause for the cardiovascular depression in this species is the use of volatile agents, whereas total intravenous anesthesia (TIVA) is associated with reduced risk (Johnston et al. 2002). For short surgical procedures, feasible combinations of injectable drugs, e.g. ketamine combinations exist (Bettschart-Wolfensberger et al. 1996). Nevertheless common practice in equine anesthesia to date is the use of inhalational anesthesia for major procedures. In order to reduce the amount of inhalational agent necessary to maintain anesthesia, and thus improve cardiovascular function, various balanced anesthetic regimes have been tested. Different authors showed a reduction of the minimal alveolar concentration (MAC) of various inhalational agents by administration of a constant rate infusion (CRI) of medetomidine, ketamine or a combination of different drugs (Bettschart-Wolfensberger et al. 2001, Muir and Sams 1992, Neges et al. 2003). Some regimes were investigated in experimental animals (Bettschart-Wolfensberger et al. 2001, Dzikiti et al. 2003, Kushiro et al. 2005, Muir and Sams 1992), some in clinical studies with caseloads of 12 to 40 horses (Spadavecchia et al. 2002, Yamashita et al. 2002). One study including 69 clinical patients compared isoflurane-lidocaine versus isoflurane-medetomidine balanced anesthesia in a randomized, prospective, blinded manner (Ringer et al. 2005). Recoveries were of better quality with isoflurane-medetomidine and maintenance of anesthesia easier than with isoflurane-lidocaine. Medetomidine is the most potent analgesic and specific alpha2-adrenoceptor agonist known at present (Kamerling et al. 1991, Virtanen et al. 1988,). Bettschart-Wolfensberger et al. (1999) demonstrated that the elimination half-life of medetomidine is short and its clearance rapid. In order to achieve constant plasma levels for certain time periods and thus a longer duration of effect than following bolus administration, medetomidine has to be used as a continuous infusion in horses. In awake ponies steady state plasma levels were reached within 30 minutes following a bolus of medetomidine followed by a constant rate infusion (CRI) for 2 hours. Plasma levels remained stable throughout the infusion (coinciding with deep sedation). Twenty minutes after the end of the infusion plasma levels were beyond limits of detection and the ponies fully alert. A bolus of medetomidine followed by continuous infusion resulted in a drop in heart rate and cardiac output for the first ten minutes. Throughout the two hour medetomidine infusion, heart rate and cardiac output did not differ from presedation values.

Nevertheless, in a study by Ringer et al. (2005) cardiac outputs were higher in the lidocaine group than in the medetomidine group. In order to test if medetomidine-isoflurane is safe for clinical use despite slightly lower cardiac outputs than found with lidocaine-isoflurane, the following study aimed at evaluating medetomidine-isoflurane in a large number of clinical cases.

\section{Material and Methods}

Animals

Anesthetic records of 296 horses and 4 donkeys which underwent surgery between February 2003 and December 2004 at the Equine Hospital of the Vetsuisse Faculty of the University of Zurich were included in the study. Horses were examined clinically before anesthesia. Emergency abdominal surgeries were excluded.

\section{Procedures}

Pre-anesthetic data recorded were breed, age, sex, weight and surgical procedure. Food but not water was routinely withheld from adult horses for 8-14 hours prior to anesthesia. Foals were allowed to suckle until 2 hours before anesthesia. In every horse a $14 G \times 160 \mathrm{~mm}$ catheter $^{1}$ was placed in a jugular vein. Horses were premedicated 30-60 minutes before induction with acepromazine ${ }^{2}(0.03 \mathrm{mg} / \mathrm{kg} \mathrm{IM})$. At the same time antibiotics and a non-steroidal anti-inflammatory drug (flunixin ${ }^{3}\left(1 \mathrm{mg} / \mathrm{kg}\right.$ ) or phenylbutazone ${ }^{4}(4 \mathrm{mg} / \mathrm{kg}) \mathrm{IV}$ ) were administered. Immediately before induction of anesthesia, horses were sedated with medetomidine ${ }^{5}(7 \mu \mathrm{g} / \mathrm{kg} \mathrm{IV)}$; one third of the dose was administered in the stable before rinsing the mouth, the remaining two thirds were administered in the induction stall slowly over 2 minutes. If the horse was not deeply sedated (e.g. no reaction when being approached to administer the ketamine), additional medetomidine was administered and the amount noted. Anesthetic induction was performed with ketamine ${ }^{6}(2.2 \mathrm{mg} / \mathrm{kg})$ and diazepam ${ }^{7}$ $(0.02 \mathrm{mg} / \mathrm{kg}) \mathrm{IV}$. Once horses were laterally recumbent, an endotracheal tube was placed and horses were hoisted onto a padded surgical table. Anesthesia was maintained with isoflurane ${ }^{8}$ in oxygen $\left(\mathrm{O}_{2}\right)$ and air and a constant rate infusion of medetomidine $(3.5 \mu \mathrm{g} / \mathrm{kg} / \mathrm{h})$. Isoflurane was delivered with a precision vaporizer ${ }^{9}$ and a large animal breathing circuit ${ }^{10}$. Medetomidine was diluted with saline $(0.9 \% \mathrm{NaCl})$ to a concentration of $0.1 \mathrm{mg} / \mathrm{ml}$ and administered with an infusion pump ${ }^{11}$ Horses breathed spontaneously, only when apnea $(>1$ minute) occurred was artificial ventilation commenced using a bag in a bottle ventilator ${ }^{12}$. The minimal fraction of inspired oxygen $\left(\mathrm{FiO}_{2}\right)$ was 0.40 . When arterial oxygen partial pressure $\left(\mathrm{PaO}_{2}\right)$ was $<80 \mathrm{~mm} \mathrm{Hg}$, the administration of air was stopped and pure oxygen was delivered. Ringers lactate was infused at a rate of $5 \mathrm{ml} / \mathrm{kg} / \mathrm{h}$ and dobutamine ${ }^{13}$ was administered to maintain mean arterial blood pressure (MABP) between 70 and $90 \mathrm{~mm} \mathrm{Hg}$, the maximum dose being $1.25 \mu \mathrm{g} / \mathrm{kg} / \mathrm{min}$. In hypotensive horses (MABP $<70$ $\mathrm{mmHg}$ ) the ringers lactate infusion was increased to 10 $\mathrm{ml} / \mathrm{kg} / \mathrm{h}$ and hetastarch ${ }^{14}$ was administered at $5 \mathrm{ml} / \mathrm{kg} / \mathrm{h}$. Hetastarch was also administered to all horses planned to recover in the hydro pool. Qualitative parameters noted during anesthesia were palpebral reflex, spontaneous blinking, nystagmus and movements. When horses showed nystagmus, a ketamine bolus was administered $(0.1 \mathrm{mg} / \mathrm{kg} \mathrm{IV})$. Thiopentone ${ }^{15}(1 \mathrm{mg} / \mathrm{kg}$ IV) was injected in cases of purposeful movement. Ketamine and thiopentone administration was recorded. A urinary catheter was placed in each horse following anesthetic induction. Cardiovascular and respiratory variables (heart rate, arterial blood pressure, respiratory rate, inspiratory and expiratory $\mathrm{O}_{2}$ and carbon dioxide $\left(E+C \mathrm{O}_{2}\right)$ ), and inspiratory and expiratory isoflurane concentration were 
measured continuously with a multi parameter monitor ${ }^{16}$ and noted every 5 minutes. Occurrence of cardiac arrhythmias was noted. Arterial blood pressure was measured invasively by connecting a facial or transverse facial arterial catheter ${ }^{17}$ to a pressure transducer ${ }^{18}$ positioned and zeroed at the level of the sternal manubrium. Arterial blood gas analysis was performed with i-STAT portable analyzer system ${ }^{19}$. The first analysis was carried out 20-40 minutes following anesthetic induction and then repeated hourly. If $\mathrm{PaO}_{2}$ was $<80 \mathrm{~mm} \mathrm{Hg}$ blood gas analysis was performed every 30 minutes.

Ten to 20 minutes before the end of surgery morphine ${ }^{20}(0.1$ $\mathrm{mg} / \mathrm{kg}(\mathrm{M})$ was administered. At the end of surgery isoflurane and medetomidine were ceased and duration of anesthesia recorded. For recovery horses were sedated with medetomidine $(2 \mu \mathrm{g} / \mathrm{kg}$ IV) 5-10 minutes following the end of surgery. Ten milliliters of phenylephrin $0.15 \%{ }^{21}$ were instilled into the nares to decongest nasal cavities. During recovery oxygen was insufflated at $15 \mathrm{~L} / \mathrm{min}$, initially through the endotracheal tube, then via the ventral nasal meatus. Time of extubation, duration of lateral and sternal recumbency and total time to standing from disconnection of the anesthetic circuit were recorded. The quality of recovery was graded on a scale of one to five, from excellent to very poor (Table 1). Six different anesthetists with varying degrees of experience conducted the 300 anesthetics and assessed recovery phases. Data were analyzed by means of descriptive statistics.

Table 1 Criteria for scoring the quality of recovery in horses Kriterien zur Einteilung der Qualität der Aufwachphase beim Pferd

\begin{tabular}{|c|l|}
\hline Score & description \\
\hline 1 & excellent, one attempt to stand, minimal or no ataxia \\
\hline 2 & good, 1-2 attempts to stand, some ataxia, horse calm \\
\hline 3 & good, but several attempts to stand, horse remains calm \\
\hline 4 & poor, more than one attempt to stand, horse excited \\
\hline 5 & very poor, bad recovery with high risk of injury \\
\hline
\end{tabular}

\section{Results}

The age of the horses ranged from 4 weeks to 28 years, with a mean age of 8 years. Among this group were 135 geldings, 103 fillies or mares and 62 colts or stallions. Breed distribution included 181 warm blood horses, 33 thoroughbreds, 82 horses of other breeds and 4 donkeys. Mean weight was 486 $\mathrm{kg}$, with a range of 42 to $735 \mathrm{~kg}$.

Surgeries performed were fracture repairs (35), arthroscopies (81), other orthopedic procedures (86), urogenital (47) and ear-nose-throat (21) surgeries and miscellaneous other procedures (32). In two horses two different procedures were performed during the same anesthesia. Ninety-one horses were not premedicated with acepromazine according to the respective anesthetist's decision. In 21 horses an additional bolus of medetomidine was necessary in order to achieve deep sedation (mean of $1.2 \mu \mathrm{g} / \mathrm{kg} \mathrm{IV}$, with a range of 0.42 $\mathrm{mcg} / \mathrm{kg}$ to $3.5 \mu \mathrm{g} / \mathrm{kg}$ ). Induction of anesthesia was smooth and uneventful in all horses. Mean duration of anesthesia was 149 minutes, with a range from 40 to 420 minutes.

In 7 horses heart rates dropped to $<20$ beats/min during the first 20 minutes following anesthetic induction. These individuals were treated with atropine $(2 \mu \mathrm{g} / \mathrm{kg} \mathrm{IV})$ and in 5 horses heart rate rose to 28-31 beats/min within 5-10 minutes. In two horses no effect was seen within 20 minutes, thus the atropine injection was repeated at the same dose, and in both cases heart rate subsequently increased to $42-51$ beats/min for 20 minutes, before decreasing again to 28-36 beats/min. In 16 horses first- or second-degree atrioventicular block was observed on the electrocardiogram during the first 45 minutes following anesthetic induction. In every single case these arrhythmias disappeared within 45 minutes without intervention. In 38 horses MABP was below $70 \mathrm{mmHg}$ for $>15 \mathrm{~min}$. In 6 of these 38 horses MABP fell below $60 \mathrm{~mm} \mathrm{Hg}$ for $>5 \mathrm{~min}$ (mean duration of 13 minutes with a range of 5 to 25 minutes). One of these 6 horses was a very young foal and one was a 28 year old Shetland pony. Another horse showed an allergic reaction with unticaria all over the body following scrubbing of the surgical site. Concurrently, its blood pressure dropped suddenly while its heart rate rose. Hetastarch and methylprednisolone were administered immediately and resolved the cardiovascular effects within 40 minutes. In another two of these 6 horses the hypotension was corrected by increasing the administration of ringers lactate and infusing hetastarch. Hetastarch was also administered in a further 25 horses; in 10 horses where blood pressure dropped below $70 \mathrm{~mm} \mathrm{Hg}$ and in 15 horses that underwent recovery in the hydro pool. Overall hetastarch was administered to 27 horses $(2-5 \mathrm{ml} / \mathrm{kg})$.

In 7 patients $\mathrm{PaO}_{2}$ fell below $60 \mathrm{~mm} \mathrm{Hg}$. Hence the inspired oxygen fraction was increased to achieve $>0.9$. In 4 of those 7 horses $\mathrm{PaO}_{2}$ consequently increased to $>60 \mathrm{~mm} \mathrm{Hg}$ within 30 minutes; in 3 horses $\mathrm{PaO}_{2}$ stayed below $60 \mathrm{~mm} \mathrm{Hg}$ until the end of anesthesia. 4 horses were artificially ventilated for the entire anesthetic duration due to persistent apnea. The other 294 horses breathed spontaneously. In 146 horses a total of 391 boli of ketamine were administered (mean of $0.3 \mathrm{mg} / \mathrm{kg}$ ) for the entire anesthesia duration. In 29 horses, a total of 71 boli of thiopentone were injected (mean 1.36 $\mathrm{mg} / \mathrm{kg}$ ). Boli of ketamine and thiopental were given more often by inexperienced anesthetists and at the beginning of the study, when anesthetists were not yet used to the new protocol. Lid reflex was in general easy to provoke and spontaneous blinking was often seen. The presence of nystagmus was only followed by purposeful movement if no ketamine was administered. If movement occurred, it was of a gentle nature and easily controlled by a bolus of thiopentone. In 74 patients no morphine was administered for recovery. Recovery data of 281 horses is presented. Four horses were euthanized because of bad prognoses due to problems unrelated to anesthesia and 15 horses recovered in the hydro pool following fracture repairs (Fig. 1). Mean \pm SD (range) time in lateral recumbency was $39.5 \pm 15.43$ (1-100) minutes, time in sternal recumbency $11.2 \pm 18.40(0-240)$ minutes and total time to standing 50.8 23.88 (1 1 -300) minutes. Quality of recovery was scored $1.3 \pm 0.62(1-4) ; 213$ recovery phases were scored 1, 45 recoveries were scored 2, 21 were assessed with a 3 and one with a 4 (Table 1)). In two horses which remained in lateral recumbency for more than one hour, $500 \mathrm{ml}$ of a hypertonic glucose solution ${ }^{22}$ was infused. One horse (with 240 minutes in sternal recumbency and 300 minutes total time to standing) was unable to get up by itself following ovariohysterectomy and was lifted with a hoisting device. The horse which remained in recovery for 100 minutes in lateral recumbency had been under anesthesia for 5 hours. Following $500 \mathrm{ml}$ of hypertonic glucose solution and some manual assistance it got up well. 


\section{Discussion}

Due to the high fatality rate in horse anesthesia there is a need for 'saver' protocols. The increasing awareness of the role of pain, central sensitization and wind-up phenomenon encourages the search for balanced anesthetic protocols. Despite ongoing research, the reasons for the high fatality rate in horses have not yet been clarified. There is evidence that most horses dying under anesthesia die because of cardiovascular problems or problems related to recovery. Known

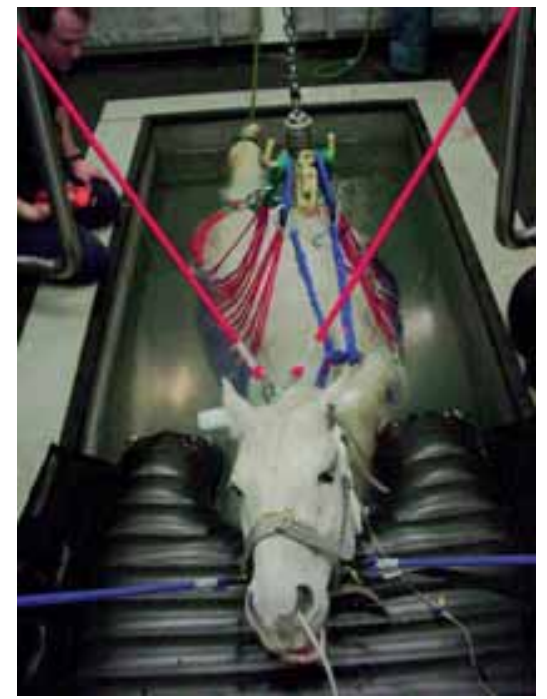

Fig 1 Recovery in the hydro pool after fracture repair. The horse is not yet touching the floor. Ringers lacate infusion is continued and oxygen supplemented.

Aufwachphase im Hydro Pool nach einer Fraktur Operation: das Pferd berührt den Boden noch nicht. Ringer Laktat wird weiterhin infundiert und Saverstoff verabreicht.

risk factors are anesthetic duration, heavy horses and fracture patients. With mean anesthetic duration of $149 \mathrm{~min}$ in this study this predisposing factor was considerably represented. The reason why all 35 fracture patients survived might be due recovery in the hydro pool, which allows a controlled recovery phase and thus reduces the risk of re-fractures.

In order to prevent the development of myopathies and neuropathies in horses, it is crucial to maintain good cardiovascular function (Young and Taylor 1993). Exact assessment of cardiovascular function is difficult under clinical conditions. Heart rate and peripheral arterial blood pressure are the only objective parameters that are monitored routinely. Maintenance of a mean arterial blood pressure above $60-70 \mathrm{~mm} \mathrm{Hg}$ is one of the most important features in equine anesthesia in order to avoid myopathies. In our study hypotension (MABP $<60 \mathrm{~mm}$ $\mathrm{Hg}$ ) occurred in $2 \%$ of the 300 horses. With increasing infusion of ringers lactate and administration of hetastarch the problem was solved in all except two patients: one of them was very old (28 years) and the other very young (4 weeks). It can be supposed that in those two individual cases the respective anesthetist tolerated the low blood pressure more than she would have done in an adult, heavy horse. The horse which developed an allergic reaction with concurrent hypotension recovered without complications. As urticaria was first noted 30 minutes after anesthetic induction, when the surgical field was prepared, it is likely that the chlorhexidine was the cause of the reaction rather than an anesthesia related drug.
Bradycardia and atrioventricular blocks of first- or seconddegree following $\alpha_{2}$-adrenoceptor agonists are common and attributed to decreased sympathetic outflow from the central nervous system and increased vagal tone from baroreceptor response to hypertension (Yamashita et al. 2000). Atrioventricular blocks recorded in $5.3 \%$ of our patients disappeared without therapy by $45 \mathrm{~min}$ after induction at the latest. In horses with heart rates $<20$ beats/min bradycardia resolved following the administration of atropine.

Equine anesthesia is inevitably associated with impaired pulmonary function and thus reduced arterial oxygenation (Gillespie et al. 1969, Trim and Wan 1990). In 7 horses (2.3\%) hypoxemia occurred. All 7 horses were heavy horses weighing between 520 and $600 \mathrm{~kg}, 6$ of them positioned in dorsal recumbency. Arterial hypoxemia is most likely to occur in horses positioned in dorsal recumbency, but can occur in laterally recumbent horses as well (Day et al. 1995, Steffey et al. 1977). In 4 horses hypoxemia resolved by changing the gas flow to pure oxygen. In the remaining 3 horses the $\mathrm{PaO}_{2}$ stayed below $60 \mathrm{~mm} \mathrm{Hg}$ for the entire duration of anesthesia. The reason why we do not administer pure oxygen from the beginning of anesthesia is that the mixture with room air may avoid the respiratory depression induced by high inspired oxygen fractions (Cuvelliez et al. 1990). Additionally, intrapulmonary shunt fraction is decreased by low $\mathrm{FiO}_{2}$ because hypoxic pulmonary vasoconstriction in underventilated areas is improved and the nitrogen fraction of air is less rapidly absorbed than $\mathrm{O}_{2}$ and can help to keep the alveoli open by slowing absorption atelectasis (Cuvelliez et al. 1990).

Whether hypoxemia could have been avoided by ventilating these horses artificially right from the start, remains to be tested. Intermittent positive pressure ventilation throughout anesthesia improves $\mathrm{PaO}_{2}$ values in horses positioned in lateral recumbency and can prevent hypoxemia in some horses positioned in dorsal recumbency (Day et al. 1995).

Anesthetic maintenance was considered to be easily controllable by all 6 anesthetists. To adjust depth of anesthesia to the needs of the patients, the anesthetists had to learn that eye reflexes, eye movement and eye position differ substantially from those seen during traditional inhalational anesthesia. Horses appear much "lighter" than during sole inhalational anesthesia although heart rate and blood pressure are stable and no movement occurs. Spontaneous blinking and tearing are often seen. The same observations were made by authors evaluating propofol-medetomidine TIVA in the horse (Mama et al. 1996). Doses of propofol combined with medetomidine were considerably lower than those described combined with other sedatives, analgesics or muscle relaxants (Bettschart-Wolfensberger et al. 2005, Mama et al. 1996, Matthews et al. 1999). The cause for this is probably the potent analgesic property of medetomidine (Kamerling et al. 1991). On that account the amount of the volatile anesthetic agent, isoflurane in this study, can be minimized. Medetomidine possesses an inhalational agent sparing effect (Bettschart-Wolfensberger et al. 2001, Neges et al. 2003). If less inhalational anesthetic can be used, pulmonary depression caused by the volatile agent is reduced. Respiratory depression occurs more often with isoflurane than with halothane (Steffey and Howland 1980). $98 \%$ of the horses in our study breathed spontaneously and only 4 horses had to be artificially ventila- 
ted following the onset of apnea. In order to minimize cardiovascular depression it is common practice in our clinic not to artificially ventilate horses that show spontaneous breathing, ignoring the arterial partial pressure of $\mathrm{CO}_{2}$. In horses, unlike in other species, no negative side effects of hypercapnia have been shown. On the contrary it was shown that hypercapnia improves cardiopulmonary performance without producing arrhythmias (Khanna et al. 1995, Wagner et al. 1990). Because of this well known fact, measured endexpiratory and arterial $\mathrm{CO}_{2}$ values were not reported and discussed in detail. Additionally, improving cardiovascular status can improve oxygen delivery to tissues. Furthermore respiratory rate and rhythm are good indicators of changes in depth of anesthesia. They allow better adjustment of optimal, superficial depth of an anesthesia.

Acepromazine was included in the protocol because it improves perfusion and arterial oxygenation in healthy normovolemic horses (Marntell et al. 2005). In a multicentre study it was concluded that the use of acepromazine reduces the risk of anesthetic death (Johnston et al. 2002). The possible reasons for this protective effect are assumed to be the reduced sensitivity of the myocardium to catecholamines, a reduced afterload through the alpha-adrenoceptor blocking effect and its smoothing influence on induction and recovery. The final decision to premedicate the individual horse in the present study with acepromazine or not was made by the respective anesthetist. Contraindications were low hematocrit (<25\%), breeding stallions because of possible priapism or an expected copious loss of blood during surgery.

It is a standard procedure in our equine clinic to administer an IV bolus of ketamine when a horse shows nystagmus and a bolus of thiopental when a horse moves. In our opinion it is not possible to make a comparison concerning the quantity of given boli directly with other studies, especially as we do not look at the isoflurane concentrations in particular. In a blinded study which compared horses undergoing isofluranemedetomidine anesthesia with horses undergoing isofluranelidocaine anesthesia, horses in the lidocaine group received significantly more boli of ketamine and thiopentone than the horses in the medetomidine group (Ringer et al. 2005). If movement occurred in our patients, it was always gentle and easily controlled.

Medetomidine increases urine production in dogs by increasing free water clearance (Burton et al. 1998). Urine production in the present study was not quantified but the amount of urine produced by the individuals seemed very high. This was also reported when medetomidine was used in combination with propofol (Bettschart-Wolfensberger et al. 2005). To avoid excessive distention of the bladder, catheterization during medetomidine CRI is considered very important.

Recovery following anesthesia is one of the critical phases of horse anesthesia. Duration of anesthesia is negatively and duration of recovery positively correlated with quality of recovery (Young and Taylor 1993). 280 of 281 horses had good, calm recoveries, 213 of such horses got up in one attempt and were scored as excellent. The one horse which was unable to get up on its own received a score of 4 . This was a mare that underwent an ovariohysterectomy in dorsal recumbency to remove a uterine tumor. During 3 hours of anesthesia her important cardiopulmonary parameters were unremarkable. After surgery the mare was unable to stand up by herself. Consequently, she was lifted with a hoisting device. The determined muscle enzyme creatine kinase was above the normal range but not high enough to suggest myopathy. Eight hours later she was still unable to stand and her cardiovascular condition was poor, thus she was euthanized in agreement with the owner. The pathologists did not find a cause for this occurrence. No muscle rupture of adductor muscles or signs of myositis were found, and the spinal cord was free from hemorrhage or lesions. Pathology only revealed a rupture in the pectoral and forearm muscles. Clinically the mare could not get up with her hind legs. Probably the rupture in her pectoral and forearm muscles was only a result of the rough recovery, and the original cause remains unclear. Equine ovariohysterectomy is an uncommonly performed but technically demanding surgery that has been associated with a high degree of invasiveness and morbidity (Delling et al. 2004, Santschi et al. 1995). We don't know whether the horse would have had a chance to survive this surgery using another anesthetic protocol.

In conclusion, after using this new anesthesia protocol in 300 equidae, it can be regarded as well suitable for anesthesia of horses undergoing routine surgery. Using this regime it is important to remember that horses have to appear much lighter under anesthesia than what we are used to from other traditional inhalational protocols. Cardiopulmonary function was generally well maintained. Incidence of hypotension and hypoxia is comparable with other equine anesthetic regime reports. The major advantage of this protocol is the usually good and calm recovery phase, which is so crucial in horses.

\section{Manufacturer's addresses}

1 Secalon ${ }^{\circledR}$ T, Ohmeda, Hatfield, UK

2 Prequillan ${ }^{\circledR}$, Fatro S.p.A., Ozzano Emilia, BO, Italy

3 Flunixine ${ }^{\circledR}$ ad us. vet., Biokema SA, Crissier, Switzerland

4 Butadion ${ }^{\circledR}$ ad us. vet., G. Streuli \& Co. AG, Uznach, Switzerland

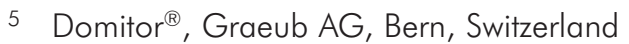

6 Narketan $^{\circledR} 10$ ad us. vet., Chassot AG, Belp-Bern, Switzerland

7 Valium ${ }^{\circledR}$ 10mg, Roche Pharma Schweiz AG, Reinach, Switzerland

8 Attane $^{T M}$ Isoflurane ad us. vet. Provet AG, Lyssach, Switzerland

9 Isoflurane Vapor 19.3, Drägerwerk AG, Lübeck, Germany

10 LAVC-2000, JD Medical distributing Co., Inc, Phoenix, Arizona, USA

11 PHOENIX D, Schoch Electronics AG, Regensdorf-Zürich, Switzerland

12 Bird Mark 7 Respirator, Medical Distributing Co., Inc., Phoenix, Arizona, USA

13 Dobutrex ${ }^{\circledR}$, Eli Lilly (Suisse) S.A., Vernier/Genève, Switzerland

14 HAES-steril ${ }^{\circledR}$ 10\%, Fresenius Pharma Schweiz AG, Stans, Switzerland

15 Pentothal ${ }^{\circledR}$, Abbott AG, Bar, Switzerland

16 Datex-Ohmeda Cardiocap/5, Anandic, AVL, Schaffhausen, Switzerland

17 Surflo ${ }^{\circledR}$ IV Catheter 22G 1", Terumo ${ }^{\circledR}$, Medical Solution Gmbh, Steinhausen, Switzerland 
18 Pressure Transducer DTX/Plus, Becton Dickinson AG, Allschwil, Switzerland

19 i- STAT ${ }^{\circledR}$ Analyser and G3+ Cartridges, Axon Lab AG, Baden-Dättwil, Switzerland

20 Morphin $\mathrm{HCl}$ 10mg, Sintetica SA, Mendrisio, Switzerland

21 Phenylephrini hydrochloridum $1.5 \mathrm{mg} / \mathrm{ml}, \mathrm{G}$. Streuli \& Co. AG, Uznach, Switzerland

22 Energidex ad us. vet., Vétoquinol AG, Belp Bern, Switzerland

\section{Literature}

Bettschart-Wolfensberger R., Taylor P. M., Sear J. W., Bloomfield M. R., Rentsch K. and Dawling S. (1996): Physiologic effects of anesthesia induced and maintained by intravenous administration of a climazolam-ketamine combination in ponies premedicated with acepromazine and xylazine. Am J Vet Res 57, 1472-1477

Bettschart-Wolfensberger R., Clarke K. W., Vainio O., Shojaee AliAbadi F. and Demuth D. (1999): Pharmacokinetics of medetomidine in ponies and elaboration of a medetomidine infusion regime which provides a constant level of sedation. Res Vet Sci 67, 41-46

Bettschart-Wolfensberger R., Jäggin-Schmucker N., Lendl C., Bettschart R. W. and Clarke K. W. (2001): Minimal alveolar concentration of desflurane in combination with an infusion of medetomidine for the anesthesia of ponies. Vet Rec 148, 264-267

Bettschart-Wolfensberger R., Kalchofner K., Neges K., Kästner S. and Fürst A. (2005) Total intravenous anaesthesia in horses using medetomidine and propofol. Vet Anaesth Analg 32, 348-354

Burton S., Lemke K. A., Ihle S. L. and Mackenzie A. L. (1998): Effects of medetomidine on serum osmolality; urine volume, osmolality and $\mathrm{pH}$; free water clearance; and fractional clearance of sodium, chloride, potassium, and glucose in dogs. Am J Vet Res 59, 756-761

Clarke K. W. and Hall L. W. (1990): A survey of anaesthesia in small animal practice: AVA/BSAVA report. J Assoc Vet Anaesth 17, 4-16

Cuvelliez S. G., Eicker S. W., McLauchlan C. and Bronson D. B. (1990): Cardiovascular and respiratory effects of inspired oxygen fraction in halothane-anesthetized horses. Am J Vet Res 51, 1226-1231

Day T. K., Gaynor J. S., Muir W. W. III, Bednarski R. M. and Mason D. E. (1995): Blood gas values during intermittent positive pressure ventilation and spontaneous ventilation in 160 anesthetized horses positioned in lateral or dorsal recumbency. Vet Surg 24, 266-276

Delling U., Howard R. D., Pleasant R. S. and Lanz O. I. (2004): Hand-assisted laparoscopic ovariohysterectomy in the mare. Vet Surg 33, 487-494

Dzikiti T. B., Hellebrekers L. J. and van Dijk P. (2003): Effects of intravenous lidocaine on isoflurane concentration, physiological parameters, metabolic parameters and stress-related hormones in horses undergoing surgery. J Vet Med A Physiol Pathol Clin Med 50, 190-195

Gibbs N. and Rodoreda P. (2005): Anaesthetic mortality rates in Western Australia 1980-2002. Anaesth Intensive Care 33, 616-22

Gillespie J. R., Tyler W. S. and Hall L. W. (1969): Cardiopulmonary dysfunction in anesthetized, laterally recumbent horses. Am J Vet Res 30, 61-72

Johnston G. M., Eastment J. K., Wood J. L. N. and Taylor, P. M. (2002): The confidential enquiry into perioperative equine fatalities (CEPEF): mortality results of Phases 1 and 2. Vet Anaesth Analg 29, 159-170

Johnston G. M., Eastment J. K., Taylor P. M. and Wood J. L. N. (2004): Is isoflurane safer than halothane in equine anaesthesia? Results from a prospective multicentre randomised controlled trial. Equine Vet J 36, 64-71

Kamerling S., Keowen M., Bagwell C. and Jochle W. (1991): Pharmacological profile of medetomidine in the equine. Acta vet Scand Suppl 87, 161-162

Khanna A. K., McDonell W. N., Dyson D. H. and P. M. Taylor (1995): Cardiopulmonary effects of hypercapnia during controlled intermittent positive pressure ventilation in the horse. Can J Vet Res 59, 213-221
Kushiro T., Yamashita K., Umar M. A., Maehara S., Wakaiki S., Abe R., Seno T., Tszuki K., Izumisawa Y. and Muir W. W. (2005): Anesthetic and cardiovascular effects of balanced anesthesia using constant rate infusion of midazolam-ketamine-medetomidine with inhalation of oxygen-sevoflurane (MKM-OS anesthesia) in horses. J Vet Med Sci 67, 379-84

Mama K. R., Steffey E. P. and Pascoe P. J. (1996): Evaluation of propofol for general anesthesia in premedicated horses. Am J Vet Res 57, 512-516.

Marntell S., Nyman G., Funkquist P. and Hedenstierna G. (2005): Effects of acepromazine on pulmonary gas exchange and circulation during sedation and dissociative anaesthesia in horses. J Vet Anaesth Analg 32, 83-93

Matthews N. S., Hartsfield S. M., Hague B., Carroll G. L. and Short Ch. E. (1999): Detomidine-propofol anesthesia for abdominal surgery in horses. Vet Surg 28, 196-201

Muir W. W. III and Sams R. (1992): Effects of ketamine infusion on halothane minimal alveolar concentration in horses. Am J Vet Res 53, 1802-1806

Neges K., Bettschart-Wolfensberger R., Müller J., Fürst A. and Kästner S. (2003): The isoflurane sparing effect of medetomidine constant rate infusion in horses. J Vet. Anaesth. 30, 88-89

Ringer S., Kalchofner K., Boller J., Fürst A. and Bettschart-Wolfensberger R. (2005): Comparison of lidocaine versus medetomidine constant rate infusion during isoflurane anesthesia in horses, in Proceedings. AVA Spring meeting 2005, 2077

Santschi E. M., Adams S. B., Robertson J. T., DeBowes R. M., Mitten L. A. and Sojka J. E. (1995): Ovariohysterectomy in six mares. Vet Surg 24, 165-171

Spadavecchia C., Stucki F., Moens Y. and Schatzmann U. (2002): Anaesthesia in horses using halothane and intravenous ketamineguaiphenesin: a clinical study. J Vet Anaesth Analg 29, 20-28

Steffey E. P., Wheat J. D., Meagher D. M., Norrie R.D, McKee D., Brown M. and Arnold J. (1977): Body position and mode of ventilation influences arterial $\mathrm{pH}$, oxygen, and carbon dioxide tensions in halothane-anesthetized horses. Am J Vet Res 38, 379-382

Steffey E. P. and Howland D. Jr. (1980): Comparison of circulatory and respiratory effects of isoflurane and halothane anesthesia in horses. Am J Vet Res 41, 821-825

Taylor P. M. (1998): Effects of hypercapnia on endocrine and metabolic responses to anaesthesia in ponies. Res Vet Sci 65, 41-46

Trim C. M. and Wan P. Y. (1990): Hypoxemia during anaesthesia in seven horses with colic. Vet Anaesth Analg 17, 45-49

Virtanen R., Savola J. M., Saano V. and Nyman L. (1988): Characterization of the selectivity, specificity and potency of medetomidine as an $\alpha 2$-adrenoceptor agonist. Eur J Pharmacol 150, 9-14

Wagner A. E., Bednarski R. M. and Muir W. W. (1990): Hemodymamic effects of carbon dioxide during intermittent positive-pressure ventilation. Am J Vet Res 51, 1922-1929

Yamashita K., Tsubakishita S., Futaok S., Ueda I., Hamaguchi H., Seno T., Katoh S., Izumisawa Y., Kotani T. and Muir W. W. (2000): Cardiovascular effects of medetomidine, detomidine and xylazine in horses. J Vet Med Sci 62, 1025-1032

Yamashita K., Muir W. W. 3rd, Tsubakishita S., Abrahamsen E., Lerch P., Izumisawa Y. and Kotani T. (2002): Infusion of guaifenesin, ketamine, and medetomidine in combination with inhalation of sevoflurane versus inhalation of sevoflurane alone for anesthesia of horses. J Am Vet Med Assoc 221, 1150-1155

Young S. S. and Taylor P. M. (1993): Factors influencing the outcome of equine anaesthesia: a review of 1,314 cases. Equine Vet J 25, 147-151

Dr. med. vet. Karin Kalchofner

Pferdeklinik der Universität Zürich

Vetsuisse Fakultät

Winterthurerstrasse 260

8057 Zürich, Switzerland

kkalchofner@vetclinics.unizh.ch 